\title{
GENOMIC VARIABILITY IN MAIZE CALLUS CULTURES OF LINE P346 AND ITS DERIVATIVE SOMACLONAL LINES
}

\author{
D. M. Maidanyuk, I. O. Andreev, K. V. Spiridonova, V. A. Kunakh
}

Institute of molecular biology and genetics NAS of Ukraine Academicain Zabolotnog str., 150, Kyiv, 03680 Ukraine

kunakh@imbg.org.ua

\begin{abstract}
Callus tissues from individual maize plants of line P346 and derived from it through in vitro tissue culture of somaclonal variants showing increased regeneration capacity have been analyzed by RAPD. As early as after two months in culture maize calli exhibited genome changes but following four months their level decreased almost twice. The emergence of homotypic DNA changes in calli obtained from different plants of individual lines was registered thus suggesting the existence of variability hot-spots within the maize genome. The somaclonal lines were shown to vary by the level of the genetic changes in culture in vitro.
\end{abstract}

Keywords: maize, tissue culture in vitro, somaclonal lines, RAPD analysis, genome rearrangements.

Introduction. The application of cell and tissue culture in vitro as an area of biotechnology is widely used in scientific research and practical experiments. Along with other methods of traditional selection this approach is employed to expedite the obtaining of new genotypes of traditional agricultural plants with certain characteristics. This approach is based on somaclonal variability, to be more precise, on variability of physiological, biochemical, and genetic features of plant cells in culture in vitro [1].

This phenomenon was used for obtaining new somaclonal maize lines with increased capability to the formation of totipotent callus and regenerative potential through the method of direct selection of calli, possessing specific features. New maize lines UKCh-5, UKCh-6, UKCh-7, UKCh-8, UKCh-9, distinguished by increased regeneration capacity, have been developed by T.M. Checheneva at the Institute of Plant Physiology and Genetics NAS of Ukraine using the method of artificial selection of inbred maize P346 line callus cultures for further application in biotechnological developments [2, 3]. Analysis, performed at V.Ya. Yurjev Institute of Plant Production of Ukrainian Academy of Agrarian Sciences (UAAS), revealed the presence of genetic differences in various agronomic 
indices between developed somaclonal lines and original P346 line (Gurjeva, unpublished data).

In the previous paper we revealed molecular and genetic differences between inbred P346 line and its somaclonal derivatives. We also revealed that somaclonal lines differ in both degree of differences from original P346 line and the level of intraline heterogeneity [4].

In the current work, to evaluate the biotechnological potential of developed somaclonal lines their genetic stability in vitro was assayed by PCR with arbitrary primers (RAPD-analysis).

Materials and Methods. The seeds of inbred Zea maize P346 (Pioneer 346) lines - UKCh-5, UKCh-6, UKCh-7, UKCh-8, and UKCh-9 - were kindly granted by the National Centre for Plant Genetic Resources of Ukraine (NCPGRU), V.Ya. Yurjev Institute of Plant Production (Kharkiv, Ukraine), NCPGRU Registration No. UB0102873, UB0103498, UB0103499, UB0103500, UB0103501, UB0103359, respectively.

Maize seeds were sterilized in $70 \%$ ethanol solution ( $2 \mathrm{~min}$ ) and then in 20\% Domestos aqueous solution $(20 \mathrm{~min})$. Then the seeds were washed 6 times with sterile distilled water and put for germination on agarose medium with half amount of salts according to Murashige-Skoog [5]. Callus cultures were obtained from individual plants with specified unique numbers. 1-2-day-old seedlings 2-5 $\mathrm{mm}$ long (plants of UKCh-5 No. 2, 3, 14; UKCh-6 No. 4, 7, 8; UKCh-7 No. 13; UKCh-8 No. 6, 9; and UKCh-9 No. 4) or air-roots after 14 days of germination (plants of UKCh-6 No. 12; UKCh-7 No. 4, 8, 9, 19; UKCh-8 No. 21; UKCh-9 No. 16) were used as explants. To induce callusogenesis explants were placed on nutrient medium of the following contents: salts according to Murashige-Skoog [5], 7.7 $\mathrm{mg} / 1$ glycine, $1.25 \mathrm{mg} / 1$ nicotine amide, $0.25 \mathrm{mg} / 1$ of thiamine, $0.25 \mathrm{mg} / 1$ of pyridoxine, $0.25 \mathrm{mg} / 1 \mathrm{cal}-$ cium pantothenate, $2 \mathrm{mg} / 1$ 2,4-D, $30 \mathrm{~g} / 1$ sucrose, 100 $\mathrm{mg} / 1$ mesoinosite, $1 \mathrm{~g} / 1$ asparagine, $8 \mathrm{~g} / 1$ agar; $\mathrm{pH} 5.7$ (prior to autoclaving). Obtained callus tissues were transferred to fresh medium every 30 days and grown in dark room at $25^{\circ} \mathrm{C}$.

DNA samples were isolated according to method, described in [6], from individual 14-day-old seed- lings (the same plants, donors of explants for obtaining callus cultures, were used) and callus tissues after 2- and 4-month cultivation in vitro. Concentration of the obtained preparations was assessed visually by the intensity of fluorescence of DNA-ethidium bromide complexes in UV light after electrophoresis in $1.5 \%$ agarose gel in relation to the control with known concentration (phage $\lambda$ DNA).

PCR reaction mixture, volume $20 \mu$, contained $1 \times \mathrm{PCR}$-buffer, $2 \mathrm{mM} \mathrm{MgCl}_{2} \quad$ (Medbioservice, Ukraine), dNTP $0.2 \mathrm{mM}$ each, 1 un Taq-polymerase (Amplisense, Russia), $0.25 \mu \mathrm{M}$ primer (Litech, Russia), 20 ng DNA. Reaction mixture was layered with $20 \mu \mathrm{l}$ of mineral oil. The following PCR programme was used: denaturation $\left(94^{\circ} \mathrm{C}, 2 \mathrm{~min}\right)$; five cycles: denaturation $\left(94^{\circ} \mathrm{C}, 30 \mathrm{sec}\right)$, renaturation $\left(38^{\circ} \mathrm{C}, 30\right.$ sec), elongation $\left(72^{\circ} \mathrm{C}, 1 \mathrm{~min}\right)$; 35 cycles: denaturation $\left(94^{\circ} \mathrm{C}, 20 \mathrm{sec}\right)$, renaturation $\left(38^{\circ} \mathrm{C}, 20 \mathrm{sec}\right)$, elongation $\left(72^{\circ} \mathrm{C}, 40 \mathrm{sec}\right)$, elongation $\left(72^{\circ} \mathrm{C}\right.$, $2.5 \mathrm{~min})$. Reaction products were divided in $2 \%$ agarose gel with ethidium bromide in $1 \times$ TBE-buffer at electric field intensity of $2 \mathrm{~V} / \mathrm{cm}$. Reaction with each primer was repeated twice.

DNAs were hydrolysed by restriction enzymes for 3 hours at conditions recommended by manufacturer (Fermentas, Lithuania). Reaction mixture, volume $30 \mu$, contained $10 \mu \mathrm{g}$ of investigated DNA and 20 un of restrictase. Hydrolysed DNA was separated in $1 \%$ agarose gel in $1 \times$ TAE-buffer at electric field gradient of $2 \mathrm{~V} / \mathrm{cm}$. Southern blotting was performed according to the method of capillary transfer, described in [7]. Polymorphic amplicons, isolated from agarose gel by silica gel adsorption using DNA extraction kit (Fermentas, Lithuania), were used as probes. DNA was labelled with $\left[\alpha-{ }^{32} \mathrm{P}\right]$-dCTP (GE Healthcare, UK) using the method of random priming, hybridisation was performed at standard conditions [7].

Results of analysis of RAPD-electrophoregrammes were presented as a binary matrix, in which the presence/absence of amplicons was indicated by $1 / 0$, respectively. Polymorphism of amplicons spectra was evaluated using unweighted pair group method with arithmetic mean (UPGMA) using POPGENE software v.1.31 [8]. Dendrogramme of genetic distances according to Nei [9] between the 
Characteristics of primer and polymorphic amplicons, discovered in genomes of callus tissues of P346 and its derivative somaclonal linеsХарактеристика праймерів і поліморфних ампліконів, знайдених у геномах калюсних тканин лінії Р346 та отриманих від

\begin{tabular}{|c|c|c|c|c|c|c|c|c|c|c|c|c|}
\hline \multirow{3}{*}{ Primer } & \multirow{3}{*}{$\begin{array}{l}\text { Nucleotide sequence } \\
\left(5^{\prime}-3^{\prime}\right)\end{array}$} & \multirow{2}{*}{\multicolumn{2}{|c|}{ Number of amplicons }} & \multirow{3}{*}{$\begin{array}{c}\text { Length of } \\
\text { polymorphic } \\
\text { amplicons, b.p. }\end{array}$} & \multicolumn{8}{|c|}{ Maize lines and Nos. of plants with polymorphic amplicons } \\
\hline & & & & & \multirow{2}{*}{$\begin{array}{c}\text { P346 } \\
(n=2)\end{array}$} & \multirow{2}{*}{$\begin{array}{c}\begin{array}{c}\text { UKCh-5 } \\
(\mathrm{n}=3)\end{array} \\
14\end{array}$} & \multicolumn{4}{|c|}{$\begin{array}{l}\text { UKCh- } 6 \\
(\mathrm{n}=4)\end{array}$} & \multicolumn{2}{|c|}{$\begin{array}{c}\text { UKCh-8 } \\
(\mathrm{n}=3)\end{array}$} \\
\hline & & Total $^{*}$ & $\begin{array}{l}\text { Polymorphic } \\
\text { amplicons }\end{array}$ & & & & 4 & 7 & 8 & 12 & 6 & 9 \\
\hline A-01 & CAGGCCCTTC & 6 & & & \multirow{10}{*}{-} & & & \multirow{10}{*}{$\begin{array}{l}(+) \\
(+) \\
(+)\end{array}$} & \multirow{10}{*}{+} & \multirow{10}{*}{+} & \multirow{10}{*}{$\begin{array}{l}+ \\
(-)\end{array}$} & \multirow{10}{*}{$\begin{array}{l}+ \\
(-)\end{array}$} \\
\hline A-12 & ATCGCACACT & 8 & & & & & & & & & & \\
\hline Ag-01 & AGGTCACTGA & 11 & & & & & & & & & & \\
\hline $\mathrm{AH}-30$ & TGGTCACTGT & 4 & & & & & & & & & & \\
\hline B-01 & GTTTCGCTCC & 4 & & & & & & & & & & \\
\hline M-06 & CTGGGCAACT & 7 & 1 & 1600 & & & & & & & & \\
\hline \multirow[t]{4}{*}{ M-07 } & CCGTGACTCA & 16 & 4 & 600 & & & & & & & & \\
\hline & & & & 680 & & & & & & & & \\
\hline & & & & 770 & & & & & & & & \\
\hline & & & & 800 & & & & & & & & \\
\hline OPA- 02 & TGCCGAGCTG & 9 & & & & \multirow{3}{*}{$(+)$} & \multirow{3}{*}{$(+)$} & & \multirow{3}{*}{$(+)$} & & \multirow{3}{*}{+} & \multirow{3}{*}{$(+)$} \\
\hline OPA-04 & AGTCAGCCAC & 9 & 1 & 800 & & & & & & & & \\
\hline 340 & GAGAGGCACC & 3 & & & & & & & & & & \\
\hline & Total & 77 & 6 & & 1 & 1 & & & & & & \\
\hline
\end{tabular}

Note: * total number of amplicons, formed using given primer, for all investigated objects, $n$ - number of analysed individual plants; + and indicate the presence or absence of amplicons of corresponding size, $(+)$ - polymorphic PCR fragments, revealed only in 2-month old callus cultures

analysed objects was constructed using MEGA software v. 3.1 [10].

Results and Discussion. To study genetic stability of somaclonal maize lines in vitro, as well as original P346 line, comparative analysis of individual plants of these lines and 2-month-old callus tissues, obtained from these tissues, was performed. Altogether, DNA from 19 plants and their callus tissues, in particular, P346 line (number of individual plants $n=$ $2)$; UKCh-5 $(n=3)$; UKCh-6 $(n=4)$; UKCh-7 $(n=5)$; UKCh-8 $(n=3)$; UKCh-9 $(n=2)$ were analysed. Genetic analysis was performed using PCR with arbitrary decanucleotide primers - RAPD-PCR [11]. The primers used had been previously applied in the investigation of genetic maize polymorphism $[12,13]$. Total number of primers used is 10 . Selected primers provided the formation of distinct products of amplification (amplicons), the number of which varied from 2 to 12 , depending on primer. Characteristic of primers and their products is presented in Table 1. Total number of analysed amplicons is 77 , six of which (7.7\%) show variation between the plants and their derivative cultivated tissues (Table 1). Polymorphic amplicons were observed in spectra of only 3 of 10 primers used, namely M-07 (4 amplicons), M-06 and OPA-04 (1 amplicon each). Polymorphism of RAPD-spectra was revealed as the differences in the presence of certain fragments and in variations in the intensity of some homologous fragments (majority of cases). Upon the comparison of spectra the quantitative variations were 


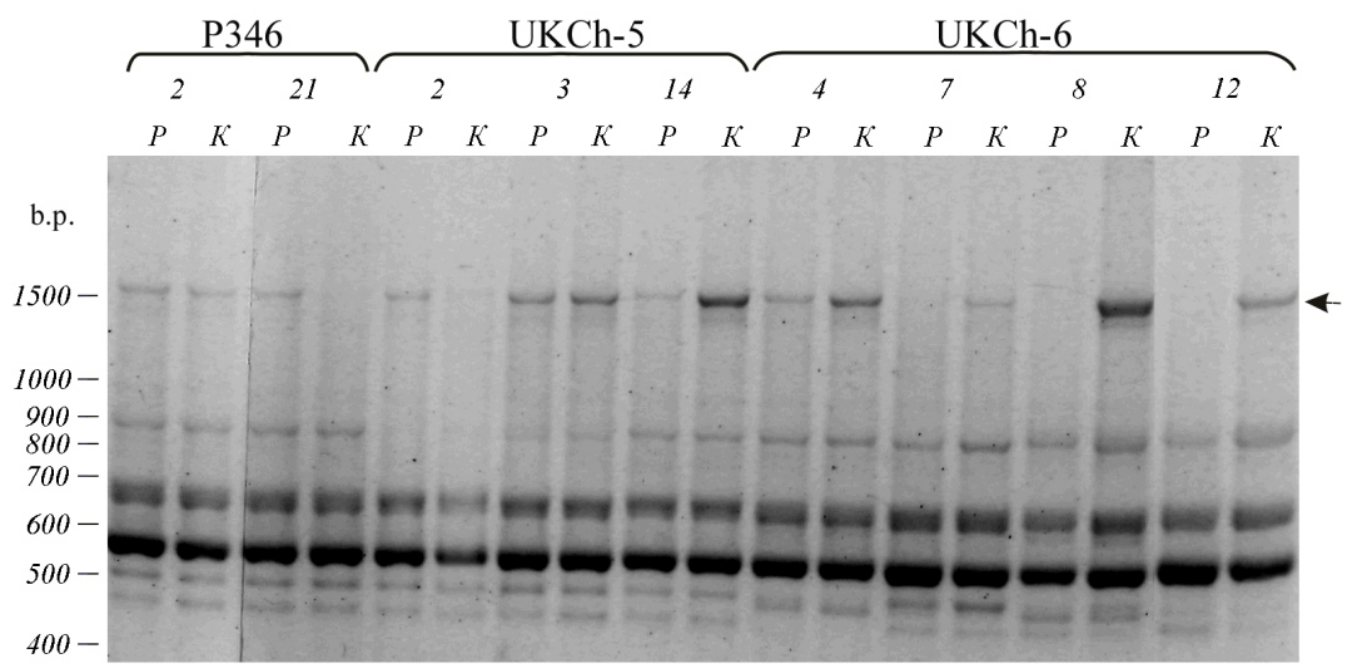

Fig.1 Spectra of DNA amplification products of intact plants (P) and 2-month-old callus tissues (K) of inbred maize lines with primer M-06. Numbers indicate plants. Arrow marks the polymorphic fragment, which differentiates callus tissues from plant - explant donor.

taken into account as presence/absence of fragment only in the case of significant (3-4 times) differences in the intensity of fluorescence of amplicons. Spectra of RAPD-fragments of intact plants and 2-month-old callus tissues of P346 line, UKCh-5 and UKCh-6, obtained using primer M-06, which demonstrate the differences in cultivated tissues from the plants, donors of explants, are presented in Fig. 1.

RAPD-analysis showed genome variability, induced by in vitro cultivation, in both somaclonal maize lines and in original P346 line. Somaclonal maize lines differed in the level of variability in culture of 2-month-old tissues, namely, in number of calli, showing polymorphic amplicons, and in number of polymorphic amplicons within spectra of callus tissues of one line (Table 1). Thus, UKCh-7 and UKCh-9 calli display no polymorphism of PCR-fragments. In P346 line, only one out of two calli obtained from different plants lost single amplicon. Similar level of variability was discovered for somaclonal line UKCh-5, where an additional fragment, absent in the spectrum of donor explant, was found in callus of one out of three plants. Callus cultures of two out of three plants of somaclonal UKCh-8 line, showed three polymorphic fragments. The highest level of polymorphism is specific to UKCh-6, i.e. one to three variable amplicons were discovered in 2-month-old callus tissues of all four investigated plants.

Some of the polymorphic amplicons were present in callus tissues of different lines of plants (Table 1), e.g. polymorphic fragment ( $~ 800$ b.p. long), amplified with OPA-04, absent in donor plants was discovered in 2-month-old callus of several plants of UKCh-5, UKCh-6, and UKCh-8 lines. The fragment of 1600 b.p. (primer M-06) revealed the differences between P346 and UKCh-6. However, the mentioned fragment disappeared in spectra of callus tissues of P346 line, at the same time it arose within spectra of three UKCh-6 plants. Noteworthy is the fact that UKCh-6 is a somaclonal variant of P346 line, obtained by selection from in vitro culture. In genome of UKCh-6 this amplicon was lost (see previous publication [4]). In current work we also observe the loss of this amplicon in callus of one of $\mathrm{P} 346$ plants. On the other hand, in callus tissues of several plants of UKCh- 6 we observed the reappearance of this amplicon. Such nonrandomness in variability of polymorphic RAPD-fragments allows supposing the existence of certain mechanisms, determining changes in unstable genome regions, revealed using aforementioned amplicons in tissues of cultures in vitro.

To study the contribution of culture duration to genetic variability of investigated maize lines in the culture of tissues in vitro we repeated the analysis of obtained callus cultures once again after 4-month-cultivation. Analysis demonstrated that in the majority of cases ( 9 of 15 polymorphism manifestations), the differences, revealed between donor plant and their 2-month-old calli, disappeared in the course of further cultivation. These unstable polymorphic fragments 


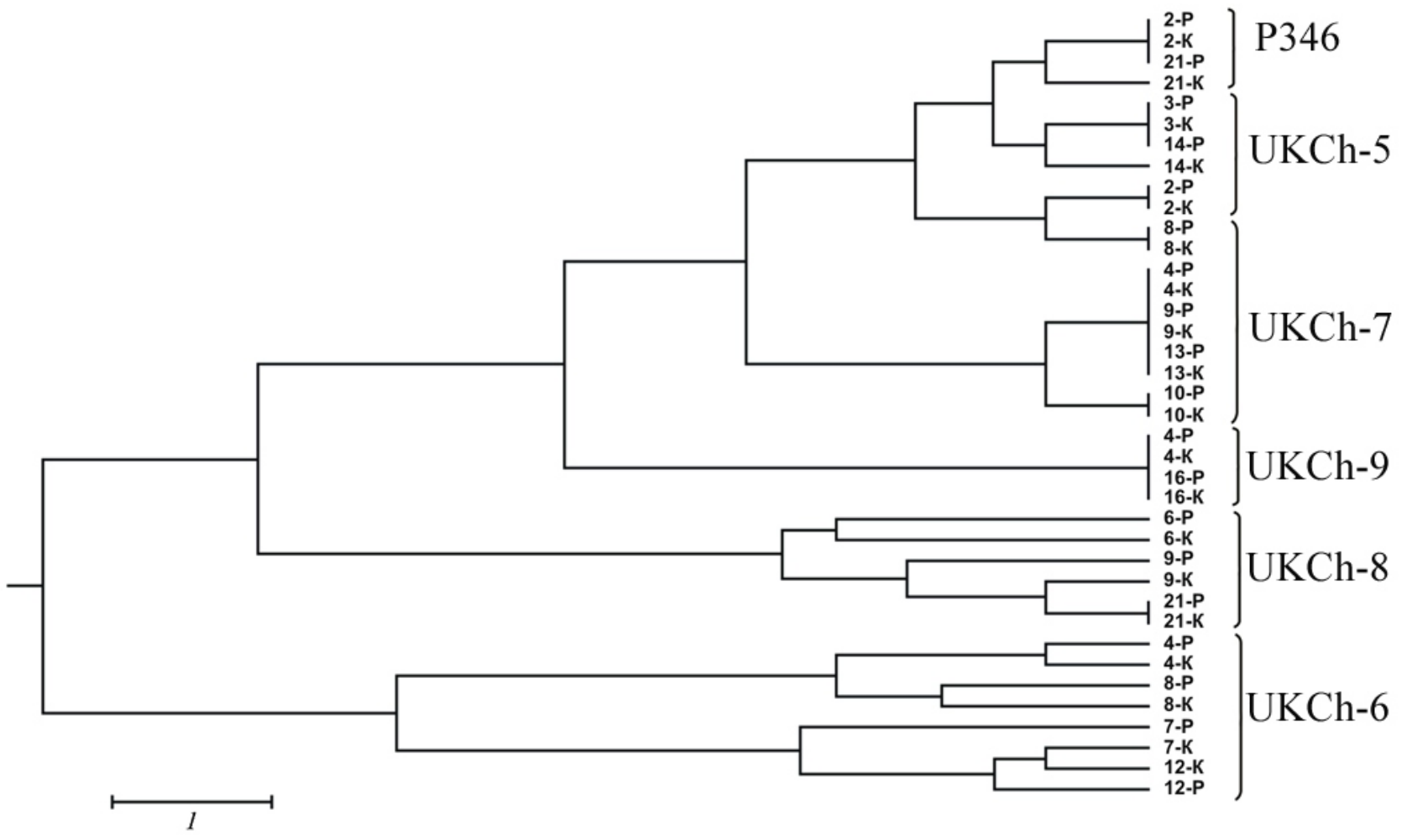

Fig.2 Dendrogramme, constructed using UPGMA on the basis of genetic distances according to Nei [9] between intact plants $(P)$ and 2-month-old calli $(K)$ of investigated maize lines

are presented in parenthesis in Table 1. After four months of cultivation, plant-callus differences persisted in one plant of P346 line, two plants of UKCh-6, and two UKCh- 8 plants, while the number of polymorphic amplicons decreased to three (3.9\%).

On the basis of RAPD-analysis conducted we calculated genetic distances according to Nei [9] and constructed a dendrogramme of relations between the investigated objects using POPGENE software v. 1.31 [8]. The objects on dendrogramme are grouped into clusters corresponding to each specific line (Fig.2). The exception is intact plant and callus tissues of UKCh-5 No.2 and UKCh-7 No.8, which formed a separate subcluster, relatively closer to UKCh-5. Line UKCh-5 was shown to be the closest to the original line of P346, followed by UKCh-7 and UKCh-9. UKCh- 8 and UKCh-6 were most remote. It has to be mentioned also that according to the level of differences between cultivated tissues and donor plants, somaclonal lines can be located in approximately the same succession. In culture of plant tissues of UKCh-7 and UKCh-9 rearrangements were not discovered at all; in UKCh-5 line there was only one polymorphic fragment revealed in callus of one plant out of three investigated. The highest level of polymorphism is specific for 2-month-old tissue cultures of UKCH-6 and UKCh-8. Despite the fact that callus tissues were obtained from different types of explants (seedlings and air-roots), the dependence between the type of explant and variability in culture in vitro was not found.

Certain polymorphic amplicons - RAPD-fragments $\sim 1600$ b.p. long (primer M-06) and $\sim 800$ b.p. (primer OPA-04) - variability of which was observed in callus tissues of plants of different lines, were used as probes for additional investigation by Southern blot hybridisation. These fragments were isolated from PCR-spectra of 2-month-old callus tissues of plant No. 8 of UKCh-6 and 2-month-old callus plant No.4 of UKCh-6 respectively. Southern blot hybridisation of 


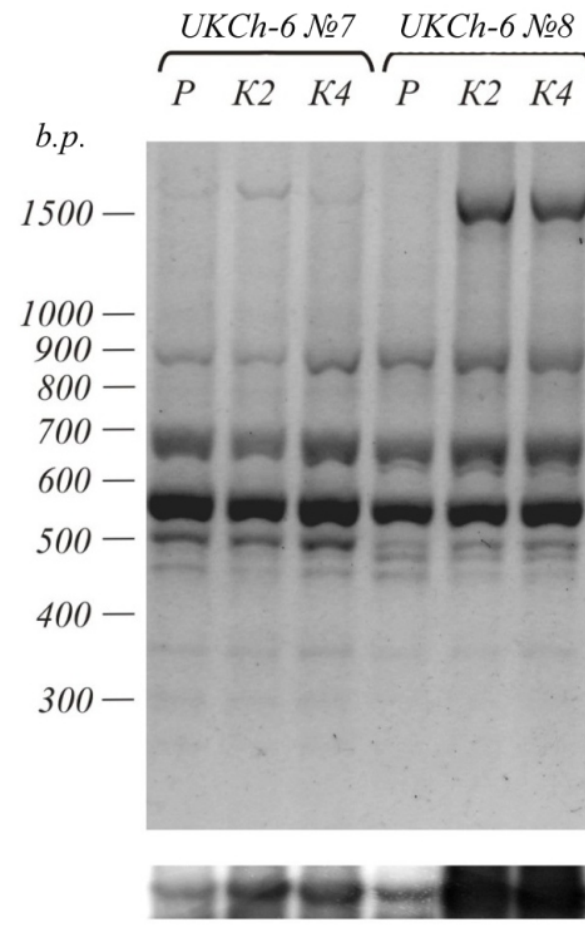

$M-06$

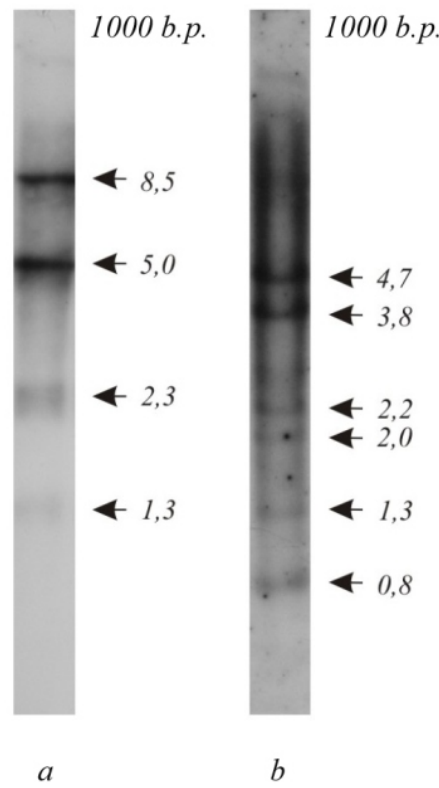

Fig.4 Contents and organization of sequences of investigated amplicons as a part of P346 line maize genome: $a$-hybridization of DNA of plant, hydrolyzed with $\mathrm{BamHI}$, with polymorphic amplicon of $\sim 1600$ b.p. long (2-month-old callus of plant No.8, somaclonal line UKCh-6, primer M-06); $b$ - hybridization of DNA of plant, hydrolyzed with HindIII endonuclease, polymorphic amplicon of $\sim 800$ b.p. long (intact plant No.4, somaclonal line UKCh-6, primer OPA-04)
Fig.3 Changes in polymorphic amplicons in tissue culture of somaclonal maize lines: top panel - results of electrophoretic separation of amplification products of plant DNA $(P)$ and their cultivated tissues of 2 and 4 month old ( $K 2$ and $K 4$ respectively); bottom panel - Southern hybridization with sequences of corresponding variable amplicons (marked by arrows on top panel); names of primers used in PCR are at the bottom.

OPA-04

polymorphic RAPD-spectra with corresponding amplicons revealed the presence of sequences, homologous to probes on all lanes, even on those where PCR products were not observed after staining with ethidium bromide (Fig.3). Thus, in this case, polymorphism of examined amplicons is most likely involved in changes in PCR products number but not their formation de novo. The results obtained do not allow concluding with certainty to what extent such changes reflect the real genetic rearrangements. One of the possible reasons is that culture cultivation results in amplicon copy number changes within the cell genome or point mutations in the region of primer hybridisation, leading to the increase in its homology to the primer.

In addition, we performed Southern blot hybridisation of polymorphic amplicons with genomic DNA of P346, treated by restriction endonucleases to analyse the contents and organisation of sequences of investigated polymorphic amplicons within the maize genome. The results of this analysis are presented in Fig.4, i.e. the presence of several large fragments in the hybridisation spectra, suggest the moderate or high copy number of sequences of investigated amplicons. 
Thus, we have analysed genetic variability in culture tissue in vitro of five somaclonal maize lines with increased capacity to the formation of totipotent callus and regenerative potential. The necessity of this investigation result from possible destabilisation of genome as a consequence of cultivation of plant cells and tissues in vitro, which is one of the reasons of somaclonal variability.

RAPD analysis was chosen as a method of investigation due to its simplicity and high efficiency. This method is successfully applied in the investigation of genome changes, induced by cultivation of plant tissues in vitro. For instance, Osipova et al. [12] revealed the changes in RAPD-spectra of plant regenerants, maize line A188; Godwin et al. found them in PCR-spectra of rice regenerants [14], Linacero et al. [15] - in PCR-spectra of rye regenerants. The application of RAPD-PCR allowed determining genomic changes in callus tissues of $\mathrm{Ce}$ reus peruvianus [16] and tomatoes [17], grown on nutrient media differing in content. At the same time there were no changes in some cases $[18,19]$.

In the current work we studied genomic rearrangements in callus tissues of maize P346 line and its somaclonal variants. Noteworthy is the fact that the changes were observed as early as after two months of in vitro cultivation. At that moment the rearrangements were detected in calli of more than a half of investigated plants -10 of 19 . The changes were predominantly revealed in the form of additional fragments in the amplicons spectra of callus tissues. Further cultivation (after 4 months of in vitro cultivation) resulted in almost 2-fold decrease in the number of both polymorphic fragments and calli with polymorphic spectra. Possible reasons for that may be quantitative changes in amplified sequences in cell genome or shift in the proportion of cells, carrying these sequences. In both cases this phenomenon is most likely to be of physiological basis and it either reflects epigenetic changes, taking place during callus formation, or it is connected with the differences in proliferation rate of various types of cells within the explant at different stages of in vitro cultivation.

Similarity of revealed genomic changes in cultivated tissues of investigated maize lines attracts special attention. In particular, polymorphism of some
PCR-fragments was observed in calli of several plants (2-5 plants, Table 1). In some cases (fragment $\sim 1600$ b.p. long, primer M-06, fragment $\sim 800$ b.p. long, primer OPA-04) the same amplicons polymorphism was observed in plant of various lines. The appearance of fragments, not discovered in calli of other plants, was detected within the spectra of one plant only - UKCh-6 No.7. These data suggest the presence of regions with increased variability in maize genome. These "hot spots" of genome instability were observed in culture in vitro of other plant species, namely, rice [20], rye [15], Populus deltoides [21], and arabidopsis [22].

On the whole, the study performed revealed that somaclonal lines differed in the level of genetic variability in culture in vitro. UKCh-7 and UKCh-9 calli fail to show any RAPD-fragments polymorphism at all. The highest level of polymorphism was revealed in the tissue culture of UKCh-6 and UKCh-8 plants. Employment of UKCh-7 and UKCh-9 in gene engineering will provide the low level of undesirable mutations at the stage of in vitro cultivation due to genomic instability of explant. On the other hand, the lines with increased genomic variability - UKCh-6 and UKCh- 8 - may be used in breeding practice for establishing of new cultivars.

Earlier we have performed molecular and genetic analysis of plants of investigated lines and determined that somaclonal variants differ in the values of genetic distances from P346, as well as in the level of intralinear heterogeneity [4]. UKCh-6 and UKCh-8 exhibited the highest intralinear heterogeneity whereas UKCh-5 - the lowest one. The most genetically distant from original P346 are the lines of UKCh-6 and UKCh-8, the least distant was UKCh-5. UKCh-7 and UKCh-9 occupy the intermediate position by the values of genetic distance from P346. Therefore, it can be supposed that there is a positive relationship between these three indices, namely level of genetic variability in vitro, intralinear heterogeneity, and genetic distance from original line. However, verification of this relationship as well as clarification of underlying mechanisms require some in-depth analysis with the greater sampling of objects.

Conclusions. Analysis of callus tissues, obtained from individual plants of inbred maize lines, using 
RAPD-PCR analysis, revealed genetic changes, induced by in vitro cultivation. Polymorphism of RAPD-spectra was observed as early as in 2-month-old callus cultures, but after 4 months of cultivation the level of polymorphism decreased almost 2-fold. The presence of homogeneous changes in DNA in calli of different lines may indicate the possible existence of hot spots of variability in maize genome. It has been determined that among somaclonal lines displaying increased regeneration capacity there were some to exhibit high genomic stability in culture in vitro, i.e. UKCh-7 and UKCh-9.

Acknowledgements. The authors are grateful to T.M. Checheneva (Institute of Plant Physiology and Genetics of NAS of Ukraine) and I.A. Gurjeva (V.Ya. Yurjev Institute of Plant Production of UAAS) for the presented seed material. The work was partially supported by Department of Science and Technology Programmes of Ministry of Science and Education of Ukraine as part of project No. 03.02.03/0014128.

\section{Д. Н. Майданюк, И. О. Андреев, Е. В. Спиридонова, В. А. Кунах}

Геномная изменчивость в каллусных культурах кукурузы линии Р346 и полученных от нее сомаклональных линий

Резюме

Методом RAPD-анализа исследованы каллусные ткани индивидуальных растений кукурузы линии Р346 и полученных от нее через культуру тканей in vitro сомаклональных линий с повышенной регенерационной способностью. Геномные изменения в культивированных тканях наблюдали уже в двухмесячных каллусах, но после четырех месяиев культивирования их уровень снижался почти вдвое. Отмечено появление однотипных изменений ДНК в каллусах, полученных от разных растений отдельных линий, что свидетельствует о возможности существования в геноме кукурузы «горячих точек» изменчивости. Показано, что сомаклональные линии отличаются по уровню генетической изменчивости в культуре in vitro.

Ключевые слова: кукуруза, культура тканей растений, сомаклональные линии, RAPD-анализ, геномные перестройки.

\section{REFERENCES}

1. Jain $S$. M. Tissue culture-derived variation in crop improvement // Euphytica.-2004.-118.- P. 153-166.

2. Чеченєва Т. М., Гур 'єва I. А. Порівняльне дослідження сомаклональних інбредних ліній кукурудзи за кількісними ознаками // Генетика в Україні на межі тисячоліть.-К.: Логос , 2001.-Т. 1.- С. 586-589.

3. Чеченева T. Н. Спонтанная и индуцированная изменчивость кукурузы in vitro: дис. ... д-ра биол. наук: 03.00.15 / Институт физиологии растений и генетики НАН Украины.-К., 2003.-302 с.

4. Майданюк Д. М., Андрєєв I. О., Спірідонова К. В., Кунах $B$. $A$. Генетичний поліморфізм сомаклональних ліній кукурудзи, отриманих від лінії Р346 // Біополімери і клітина.-2007.-23, № 4.-C. 324-331.

5. Murashige T., Skoog F. A revised medium for rapid growth and bioassays with tobacco tissue cultures // Physiol. Plant.-1962.-15.-P. 473-497.

6. Rogers S. O., Bendich A. J. Extraction of DNA from milligram amounts of field plant tissues // Plant Mol. Biol.-1985.-5.-P. 69-76.

7. Маниатис Т., Фрич Э., Сэмбрук Дж. Методы генетической инженерии. Молекулярное клонирование.-М.: Мир, 1984.-480 c.

8. Yeh F. C., Rongcai Y., Boyle T. POPGENE. Version 1.31.Edmonton: Univ. Alberta, 1999.

9. Nei M. Genetic distance between populations // Amer. Naturalist.-1972.-106.- P. 283-292.

10. Kumar S., Tamura K., Nei M. MEGA 3: Integrated software for molecular evolution genetics analysis and sequences alignment // Briefin. Bioinf.-2004.-5.-P. 150-163.

11. Williams J. G. K., Kubelik A. R., Livak K. J., Rafalski J. A., Tingey $S$. $V$. DNA polymorphisms amplified by arbitrary primers are useful as genetic markers // Nucl. Acids Res.-1990.-18.-P. 6531-6535.

12. Осипова Е. С., Ковеза О. В., Троицкий А. В., Долгих Ю. И., Шамина 3. Б., Гостимский С. А. Выявление специфических фрагментов у сомаклонов кукурузы и создание на их основе SCAR-маркеров // Генетика.-2003.-39, № 12.C. $1664-1672$.

13. Майданюк Д. Н., Андреев И. О., Спиридонова Е. В., Чеченева T. Н., Кунах В. А. Геномная изменчивость линии кукурузы Black Mexican Sweet Corn C456 в культуре in vitro: результаты RAPD-анализа // Вісн. Укр. тов-ва генетиків і селекціонерів.-2006.-4, № 1.-C. 58-67.

14. Godwin I. D., Sangduen N., Kunanuvatchaidach R., Piperidis G., Adkins $S$. W. RAPD polymorphisms among variant and phenotypically normal rice (Oryza sativa var. indica) somaclonal progenies // Plant Cell Rep.-1997.16.-P. 320-324.

15. Linacero R., Freitas Alves E., Vazquez A. M. Hot spots of DNA instability revealed through the study of somaclonal variation in rye // Theor. and Appl. Genet.-2000.-100.P. 506-511.

16. Mangolin C. A., Ottoboni L. M. M., Machado M. F. P. S. RAPD markers to evaluate callus tissue of Cereus peruvianus 
Mill. (Cactaceae) maintained in different growth regulator combinations // Biochem. Genet.-2002.-40.-P. 351-358.

17. Bogani P., Simoni A., Lio P., Scialpi A., Buiatti M. Genome flux in tomato cell clones cultured in vitro in different physiological equilibria. II. A RAPD analysis of variability // Genome.-1996.-9.-P. 846-853.

18. Fourre J. L., Berger P., Niquet L., Andre P. Somatic embryogenesis and somaclonal variation in Norway spruce: morphogenetic, cytogenetic and molecular approaches // Theor. and Appl. Genet.-1997.- 94.- P. 159-169.

19. Gallego J., Martinez I., Celestino C., Toribio M. Somaclonal variation using RAPDs in Quercus suber L. Somatic embryos // Int. J. Plant Sci.-1997.-158.-P. 563-567.
20. Xie Q. J., Oard J. H., Rush M. C. Genetic analysis of a purple-red hull rice mutation derived from tissue culture // J. Hered.-1995.-86.-P. 154-156.

21. Rani V., Parida A., Raina S. N. Random polymorphic DNA (RAPD) markers for genetic analysis in micropropagated plants of Populus deltoides Marsh. // Plant Cell Rep.-1995.-14.-P. 459-462.

22. Polanco C., Ruiz M. L. AFLP analysis of somaclonal variation in Arabidopsis thaliana regenerated plants // Plant Sci.-2002.-162.-P. 817-824.

UDC 575.22:633.15+581.143.6

Recieved 18.06.07 